\title{
APLIKASI KOMPOS TANDAN KOSONG KELAPA SAWIT DAN DOLOMIT PADA MEDIUM SUB SOIL INCEPTISOL TERHADAP BIBIT KELAPA SAWIT (Elaeis guineensis Jacq.) DI PEMBIBITAN UTAMA
}

\author{
(Application of Empty Palm Fruit Bunch Compost and Dolomite in Medium Sub Soil Inceptisol to \\ Seedling Palm Oil ( Elaeis guineensis Jacq. ) in Main Nursery)
}

\author{
Al Ichsan Amri, Armaini Armaini dan Mazmur Rahmat Amindo Purba \\ Fakultas Pertanian Universitas Riau \\ Kampus Bina Widya Km. 12,5 Simpang Baru Pekanbaru (28293) \\ email : iksan.amri@ymail.com HP: 08127628671
}

\begin{abstract}
The purpose of this research is to determine the best combination of empty palm fruit bunch compost and dolomite that could support the growth of palm oil plantations seedling in a main nursery. This research was conducted in the experimental field, Agriculture Faculty, University of Riau from April to July 2015. The research used Completely Randomized Design that consist of two factors with three replications. The first factor was application the compost bunches empty palm oil : $(37,5,75$ and 112,5 g/polybag). The second factor was dolomite application (CaMg (CO3)2) : (9, 18 and 30 g/polybag). The research results showed that $112,5 \mathrm{~g} /$ polybag and dolomite $18 \mathrm{~g} / \mathrm{polybag}$ was the best combination because could increase hump diameter of seedling, height of seedlings, number of leaves, volume of roots, root shoot ratio and and dry weight of seedlings.
\end{abstract}

Key words : Compost bunches empty, dolomite, sub soil Inceptisol, seedling palm oil.

\section{PENDAHULUAN}

Kelapa sawit (Elaeis guineensis Jacq.) merupakan komoditas primadona yang banyak diusahakan oleh masyarakat maupun badan usaha. Luas areal perkebunan kelapa sawit di Provinsi Riau pada tahun 2013 mencapai 2.339.172 ha dengan produksi sebesar 7.570.854 ton, dari luas areal lahan tersebut tercatat luas areal tanaman dalam kondisi tua dan tidak produktif mencapai 10.247 ha (Badan Pusat Statistik Provinsi Riau, 2014). Untuk menggantikan tanaman dalam kondisi tua dan tidak produktif adalah sebanyak 1.393.592 bibit (jika bibit/ha = 136). Oleh sebab itu, perlu penanganan secara tepat untuk memperoleh bibit yang berkualitas. Salah satu faktor yang menentukan bibit yang berkualitas adalah penggunaan medium.

Media pembibitan kelapa sawit pada umumnya menggunakan tanah lapisan atas (top soil) dengan kesuburan yang baik. Pada daerah tertentu top soil telah sulit didapatkan, hal itu disebabkan oleh penggunaannya yang terus menerus atau terkikis akibat erosi sehingga ketersediaannya semakin menipis. Oleh sebab itu salah satu medium yang dapat digunakan adalah tanah lapisan bawah (sub soil), khususnya sub soil Inceptisol.
Tanah Inceptisol merupakan tanah yang belum matang (immature) yang perkembangan profilnya lebih lemah dibanding dengan tanah matang dan masih banyak menyerupai sifat bahan induknya. Pada tanah Inceptisol khususnya lapisan bawah memilikikelemahan, diantaranya unsur hara yang terbatas dan kemasaman yang relatif tinggi (Hardjowigeno, 2007). Penggunaan sub soil Inceptisol diperkirakan akan menghasilkan pertumbuhan bibit kelapa sawit yang baik bila dalam aplikasinya dicampur dengan pupuk organik seperti kompos.

Kompos tandan kosong kelapa sawit (TKKS) adalah salah satu limbah padat yang dihasilkan dari pengolahan pabrik kelapa sawit ysng telah mengalami dekomposisi. Kompos TKKS merupakan bahan organik yang mengandung unsur hara utama $\mathrm{N}, \mathrm{P}, \mathrm{K}$ dan $\mathrm{Mg}$ dan bermanfaat sebagai pembenah medium tanam (Darmosarkoro dan Winarna, 2001), mampu memperbaiki sifat fisik tanah, dapat pula meningkatkan efisiensi pemupukan sehingga pupuk yang digunakan untuk pembibitan kelapa sawit dapat dikurangi (Lalang Buana et al., 2003). Kandungan nutrisi kompos TKKS : C 35\%, N 2,34\%, C/N 15, P $0,31 \%$, K 5,53\%, Ca 1,46\%, Mg 0,96\%, dan Air 52\% (Widiastuti dan Panji, 2007). Kelarutan unsur-unsur hara yang diperlukan 
bagi pertumbuhan tanaman, mengurangi resiko sebagai pembawa hama tanaman, merupakan pupuk yang tidak mudah tercuci oleh air, dan dapat diaplikasikan pada berbagai musim (Fauzi et al., 2002). Pemberian kompos TKKS pada medium sub soil Inceptisol kurang maksimal, maka perlu penambahan kapur guna mengatasi kemasaman tanah.

Pemberian kapur ke dalam tanah yang dimaksudkan untuk mengatasi kemasaman tanah. Kapur yang biasa digunakan dalam pertanian salah satunya adalah dolomit. Kapur dolomit dapat memperbaiki karakteristik tanah antara lain meningkatkan $\mathrm{pH}$, meningkatkan ketersediaan hara $\mathrm{Ca}$ dan $\mathrm{Mg}$ yang dibutuhkan tanaman, menambah ketersediaan unsur-unsur $P$ dan Mo, mengurangi keracunan $\mathrm{Fe}, \mathrm{Mn}$, dan $\mathrm{Al}$, dan memperbaiki kehidupan mikroorganisme. Pemberian kompos TKKS dan dolomit diharapkan dapat menunjang pertumbuhan bibit kelapa sawit selama di pembibitan utama, khususnya pada medium sub soil Inceptisol. Penelitian ini bertujuan mengetahui pengaruh aplikasi kombinasi kompos tandan kosong kelapa sawit dan dolomit pada medium sub soil inceptisol untuk pembibitan kelapa sawit (Elaeis guineensis Jacq.) di pembibitan utama.

\section{BAHAN DAN METODE}

Penelitian ini dilaksanakan di kebun percobaan Fakultas Pertanian Universitas Riau, Kampus Bina Widya Km 12,5 Kelurahan Simpang Baru, Kecamatan Tampan, Pekanbaru. Penelitian ini dilaksanakan selama 4 bulan yang dimulai dari bulan April sampai Juli 2015. Bahan-bahan yang digunakan adalah bibit kelapa sawit varietas Tenera umur 4 bulan, tanah Inceptisol (sub soil) kedalaman $20-40 \mathrm{~cm}$ dari permukaan tanah, polybag hitam ukuran $35 \mathrm{~cm} \times 40 \mathrm{~cm}$,
TKKS dan dolomit. Alat yang digunakan adalah cangkul, parang, meteran, ayakan, terpal, polybag hitam ukuran $35 \mathrm{~cm} \times 40 \mathrm{~cm}$, gelas ukur, ember, gembor, tali rafia, timbangan analitik, cutter, handsprayer, sarung tangan, amplop padi, kertas label, oven, kamera dan alat tulis.

Penelitian dilakukan secara eksperimen dengan menggunakan Rancangan Acak Lengkap 2 faktorial. Faktor pertama adalah kompos TKKS : 37,5, 75 dan 112,5 g/polybag. Faktor kedua adalah dolomit : 9, 18 dan $27 \mathrm{~g} /$ polybag. Setiap kombinasi perlakuan terdiri dari 2 bibit dan diulang 3 kali. Parameter yang diamati adalah perubahan $\mathrm{pH}$, pertambahan tinggi bibit, pertambahan jumlah daun, pertambahan diameter bonggol, volume akar, ratio tajuk akar dan berat kering bibit. Hasil sidik ragam diuji lanjut dengan menggunakan uji Duncan pada taraf 5\%.

\section{HASIL DAN PEMBAHASAN}

\section{Perubahan pH Medium Sub Soil Inceptisol}

Data Tabel 1 bahwa kombinasi pemberian kompos TKKS dan dolomit cenderung meningkatkan $\mathrm{pH}$ medium sub soil Inceptisol. Pertambahan $\mathrm{pH}$ tertinggi ditunjukkan oleh media dengan pemberian kombinasi kompos TKKS 112,5 g/polybag dan dolomit $27 \mathrm{~g} /$ polybag yaitu 0,70 , sehingga $\mathrm{pH}$ yang diperoleh meningkat menjadi 5,82 . Peran kompos TKKS dalam meningkatkan $\mathrm{pH}$ didukung oleh pemberian dolomit pada medium. Kuswandi (1993) menyatakan pemberian dolomit berperan dalam menambahkan unsur hara $\mathrm{Ca}$ dan $\mathrm{Mg}$. Suplai hara $\mathrm{Mg}$ dan $\mathrm{Ca}$ dapat menggeser kedudukan $\mathrm{H}^{+}$di permukaan koloid sehingga menetralisir kemasaman tanah.

Tabel 1. Hasil Pengamatan Ph Medium Sub Soil Inceptisol Setelah Pemberian Kompos TKKS dan Dolomit

\begin{tabular}{ll}
\hline Kompos TKKS + Dolomit $(\mathrm{g} /$ polybag $)$ & $\mathrm{pH}$ \\
\hline $37,5+9$ & 5,21 \\
$37,5+18$ & 5,30 \\
$37,5+27$ & 5,40 \\
$75+9$ & 5,48 \\
$75+18$ & 5,56 \\
$75+27$ & 5,58 \\
$112,5+9$ & 5,64 \\
$112,5+18$ & 5,69 \\
$112,5+27$ & 5,82 \\
\hline
\end{tabular}

Peningkatan $\mathrm{pH}$ medium menunjukkan pengaruh dari kompos TKKS dan dolomit. Kompos TKKS mampu menurunkan ion $\mathrm{H}^{+}$ hasil dari hidrolisis $\mathrm{Al}^{3+}$ dan $\mathrm{Fe}^{3+}$. Jimianto (2011) melaporkan dengan semakin banyak takaran kompos TKKS yang diberikan (50- 
Jurnal Agroteknologi, Vol. 8 No. 2, Februari $2018: 1$ - 8

$150 \mathrm{~g} /$ polibag) semakin besar pengaruhnya terhadap sifat kimia tanah, terutama terjadi peningkatan $\mathrm{pH}$ tanah $\left(\mathrm{H}_{2} \mathrm{O}\right.$ dan $\left.\mathrm{KCl}\right)$ ultisol.

\section{Pertambahan Tinggi Bibit, Jumlah Daun dan Diameter Bonggol}

Tabel 2 menunjukkan bahwa kombinasi pemberian kompos TKKS 112,5 g/polybag dengan dolomit 27 g/polybag menunjukkan pertambahan tinggi bibit tertinggi yaitu $22,86 \mathrm{~cm}$, namun berbeda tidak nyata dengan semua kombinasi perlakuan kecuali kombinasi perlakuan kompos TKKS 37,5 g/polybag dengan dolomit pada pada taraf 9 g/polybag dan $18 \mathrm{~g} /$ polybag. Hal ini diduga dipengaruhi oleh faktor genetik dari tanaman tersebut, dimana pada tanaman perkebunan membutuhkan waktu yang cukup lama untuk pertumbuhan tinggi tanaman.

Tabel 2. Pertambahan Tinggi Bibit, Jumlah Daun dan Diameter Bonggol Bibit pada Medium Sub Soil Inceptisol Setelah Pemberian Kompos Tkks dan Dolomit

\begin{tabular}{|c|c|c|c|c|}
\hline \multirow{2}{*}{$\begin{array}{c}\text { Kompos TKKS } \\
\text { (g/polybag) }\end{array}$} & \multicolumn{3}{|c|}{ Dolomit (g/polybag) } & \multirow{2}{*}{ Rata-rata } \\
\hline & 9 & 18 & 27 & \\
\hline \multicolumn{5}{|c|}{----- Pertambahan tinggi bibit $(\mathrm{cm})$----- } \\
\hline 37,5 & $13.61 \mathrm{c}$ & $17.81 \mathrm{bc}$ & $18.88 \mathrm{ab}$ & $16.77 \mathrm{~b}$ \\
\hline 75 & $18.70 \mathrm{ab}$ & $19.43 \mathrm{ab}$ & $20.76 \mathrm{ab}$ & $19.63 \mathrm{a}$ \\
\hline 112,5 & $20.04 \mathrm{ab}$ & $21.83 a b$ & $22.86 \mathrm{a}$ & $21.58 \mathrm{a}$ \\
\hline Rata-rata & $17.45 \mathrm{~b}$ & $19.69 \mathrm{ab}$ & $20.83 a$ & \\
\hline \multicolumn{5}{|c|}{----- Pertambahan jumlah daun (helai) ----- } \\
\hline 37,5 & $5.00 \mathrm{f}$ & 5.16 ef & 5.33 def & $5.16 \mathrm{c}$ \\
\hline 75 & 5.83 cde & $6.00 \mathrm{~cd}$ & $6.16 \mathrm{c}$ & $6.00 \mathrm{~b}$ \\
\hline 112,5 & $6.33 \mathrm{bc}$ & $7.00 \mathrm{ab}$ & $7.33 \mathrm{a}$ & $6.88 \mathrm{a}$ \\
\hline Rata-rata & $5.72 \mathrm{~b}$ & $6.05 \mathrm{ab}$ & $6.27 \mathrm{a}$ & \\
\hline \multicolumn{5}{|c|}{----- Pertambahan diameter bonggol (helai) ----- } \\
\hline 37,5 & $1,93 \mathrm{~d}$ & $2,15 \mathrm{bc}$ & $2,15 \mathrm{bc}$ & $2,08 \mathrm{~b}$ \\
\hline 75 & $2,09 \mathrm{bcd}$ & $2,03 \mathrm{~cd}$ & $2,02 \mathrm{~cd}$ & $2,04 \mathrm{~b}$ \\
\hline 112,5 & $2,17 \mathrm{bc}$ & $2,21 a b$ & $2,37 \mathrm{a}$ & $2,25 \mathrm{a}$ \\
\hline Rata-rata & $2,06 \mathrm{~b}$ & $2,13 \mathrm{ab}$ & $2,18 \mathrm{a}$ & \\
\hline
\end{tabular}

Keterangan: Angka yang diikuti oleh huruf kecil yang sama pada setiap perlakuan utama dan kombinasinya, tidak berbeda nyata menurut uji jarak berganda Duncan $5 \%$.

Pemberian kompos TKKS dosis 112,5 $\mathrm{g} /$ polybag menunjukkan pertambahan tinggi bibit kelapa sawit tertinggi yaitu $21,58 \mathrm{~cm}$, hanya berbeda nyata dengan dosis 37,5 g/polybag. Salisbury dan Ross (1995) menyatakan bahwa jika unsur hara yang dibutuhkan tanaman sudah mencapai kondisi yang optimal, walaupun dilakukan peningkatan dosis pupuk tidak akan memberikan peningkatan yang berarti terhadap pertumbuhan dan hasil tanaman. Hal ini terbukti pada peningkatan dosis menjadi 75 g/polybag.

Bibit kelapa sawit membutuhkan unsur hara $\mathrm{N}$ yang cukup tinggi untuk membentuk sel dan jaringan baru pada masa pertumbuhan vegetatif, khususnya tinggi bibit kelapa sawit. Notohadiprawiro et al. (2006) menyatakan bahwa nitrogen sangat dibutuhkan oleh tanaman pada fase pertumbuhan vegetatif, khususnya pertumbuhan batang yang memacu pertumbuhan tinggi tanaman. Menurut Sarief (1993) bahwa pertumbuhan tinggi tanaman dipengaruhi oleh ketersediaan nitrogen yang cukup yang berperan dalam proses pembelahan sel.
Pemberian dolomit 27 g/polybag menunjukkan pertambahan tinggi bibit kelapa sawit tertinggi yaitu $20,83 \mathrm{~cm}$ berbeda nyata dengan dosis $9 \mathrm{~g} /$ polybag, namun berbeda tidak nyata dengan dosis $18 \mathrm{~g} /$ polybag. Hal ini dikarenakan pada dosis dolomit $18 \mathrm{~g} /$ polybag sudah cukup menyumbangkan unsur hara dan dapat diserap dengan baik untuk mendukung pertumbuhan bibit kelapa sawit. Pengapuran menggunakan dolomit dapat meningkatkan $\mathrm{pH}$ tanah, menyediakan unsur $\mathrm{Ca}$ dan $\mathrm{Mg}$, memperbaiki sifat kimia, fisik dan biologi tanah sehingga unsur hara dapat diserap oleh akar dengan baik. Menurut Ismanto (1994) dolomit memiliki kandungan $\mathrm{Ca}$ yang berfungsi sebagai penyusun dinding sel, pembelaan sel dan untuk tumbuh.

Tabel 2 menunjukkan bahwa kombinasi pemberian kompos TKKS 112,5 g/polybag dan dolomit 27 g/polybag menunjukkan pertambahan jumlah daun tertinggi yaitu 7,33 helai, berbeda nyata dengan semua kombinasi perlakuan kecuali kombinasi perlakuan kompos TKKS 112,5 g/polybag dengan dolomit dosis 18 g/poybag. Hal ini dikarenakan pada dosis ini unsur hara cukup tersedia dan dapat diserap dengan baik oleh perakaran tanaman. 
Meningkatnya pertambahan jumlah daun pada perlakuan ini disebabkan pemberian kompos TKKS yang dapat memenuhi kebutuhan unsur hara bibit kelapa sawit, yang dibarengi dengan pemberian dolomit sehingga berpengaruh baik untuk meningkatkan ketersediaan hara bagi tanaman. Kompos TKKS memiliki kandungan unsur hara seperti $\mathrm{N}, \mathrm{P}, \mathrm{K}$ dan $\mathrm{Mg}$ sehingga dapat memenuhi kebutuhan unsur hara di tanah. Penambahan kapur dolomit berperan meningkatkan $\mathrm{pH}$ dan menyediakan unsur $\mathrm{Ca}$ dan $\mathrm{Mg}$ sehingga kombinasi kedua perlakuan ini bersinergi meningkatkan pertambahan jumlah daun bibit kelapa sawit.

Menurut Novizan (2005) peran unsur hara pada tanaman diperlukan untuk proses pembelahan dan perpanjangan sel, selain itu unsur hara juga berperan dalam pembentukan khlorofil yang diperlukan dalam proses fotosintesis untuk menghasilkan karbohidrat. Menurut Lakitan (2010), pengapuran dapat meningkatkan $\mathrm{pH}$, ketersediaan unsur $\mathrm{Ca}$, Mg,menurunkan Al-dd dan kejenuhan Al. Kandungan $\mathrm{Ca}$ dan $\mathrm{Mg}$ pada kapur dolomit berfungsi sebagai penyusun khlorofil dan sebagai aktifator berbagai enzim dalam berbagai reaksi fotosintesis, respirasi dan pembentukan RNA dan DNA.

Data pada Tabel 2 menunjukkan bahwa pemberian kompos TKKS 112,5 g/polybag merupakan pertambahan jumlah daun tertinggi yaitu 6,88 helai. Jumlah daun diakhir penelitian untuk perlakuan ini adalah 10,04 helai (sudah melebihi standar pertumbuhan). Jumlah ini berbeda nyata dengan pertambahan jumlah daun pada dosis 37,5 g/polybag dan 75 g/polybag. Pertambahan jumlah daun yang berbeda nyata pada faktor ini dikarenakan kompos TKKS mampu menyediakan unsur hara yang dibutuhkan tanaman untuk pertambahan jumlah daun seperti unsur nitrogen dan fosfor.

Unsur hara $\mathrm{N}$ dan $\mathrm{P}$ berperan dalam pembentukan sel-sel baru serta komponen utama penyusun senyawa organik dalam tanaman yang mempengaruhi pertumbuhan vegetatif tanaman. Menurut Lakitan (2010) ketersediaan unsur $\mathrm{N}$ dan $\mathrm{P}$ akan mempengaruhi daun dalam hal bentuk dan jumlah. Menurut Gardner et al. (1991), N merupakan bahan penting penyusun asam amino serta esensial untuk pembelahan sel, pembesaran sel, dan untuk pertumbuhan. Novizan (2005) menyatakan bahwa nitrogen dibutuhkan dalam jumlah relatif besar pada setiap pertumbuhan tanaman, khususnya pada tahap pertumbuhan vegetatif, seperti peningkatan jumlah daun. Menurut Hardjowigeno (2007), unsur hara $P$ berperan dalam pembelahan dan pembentukan organ tanaman. Pembelahan dan pembesaran selsel muda akan membentuk primordial daun.

Pada faktor dolomit, pertambahan jumlah daun tertinggi di tunjukkan pada dosis $27 \mathrm{~g} /$ polyba yaitu 6,27 dengan jumlah daun di akhir penelitian sebanyak 9,32 helai (sudah mencapai standar pertumbuhan). Pertambahan jumlah daun pada faktor dolomit cenderung meningkat walaupun pada dosis $27 \mathrm{~g} /$ polybag berbeda tidak nyata dengan dosis $18 \mathrm{~g} /$ polybag. Peningkatan pertambahan jumlah daun pada faktor dolomit disebabkan oleh sumbangan unsur hara berupa $\mathrm{Ca}$ dan $\mathrm{Mg}$ dari kapur dolomit, serta membantu tersedianya unsur hara makro dan mikro lainnya. Sutedjo dan Kartasapoetra (2002), menyatakan bahwa dengan adanya pengapuran pada tanah yang relatif masam, absorpsi unsur-unsur Mo, $\mathrm{P}$ dan $\mathrm{Mg}$ akan meningkat dan pada waktu yang bersamaan akan menurunkan secara nyata konsentrasi $\mathrm{Fe}$, Al dan $\mathrm{Mn}$ yang dalam keadaan masam unsur-unsur ini dapat mencapai konsentrasi yang bersifat racun bagi tanaman.

Tabel 2 menunjukkan bahwa kombinasi pemberian kompos TKKS 112,5 g/polybag dan dolomit 27 g/polybag menunjukkan pertambahan diameter bonggol bibit kelapa sawit tertinggi yaitu $2,37 \mathrm{~cm}$ dengan diameter bonggol diakhir penelitian sebesar $3,32 \mathrm{~cm}$. Hasil ini berbeda nyata dengan semua kombinasi perlakuan kecuali kombinasi perlakuan kompos TKKS 112,5 g/polybag dan dolomit 27 g/polybag. Hal ini disebabkan kandungan unsur hara kompos TKKS yang dapat memenuhi kebutuhan unsur hara bibit kelapa sawit, kemudian ditambah dengan fungsi kapur yaitu meningkatkan $\mathrm{pH}$ dan mengandung unsur hara $\mathrm{Ca}$ dan $\mathrm{Mg}$. Unsur hara $\mathrm{Ca}$ berfungsi pada pembelahan sel, penyusun dinding sel tanaman dan untuk tumbuh, sedangkan $\mathrm{Mg}$ berfungsi dalam pembentukan khlorofil, sistem enzim dan pembentukan minyak untuk mendukung aktifitas mikroorganisme dalam tanah sehingga pada akhirnya mampu memenuhi kebutuhan unsur hara yang dibutuhkan bibit dan mendukung proses fisologis tanaman seperti fotosintesis. Terpenuhinya kebutuhan unsur hara pada tanaman akan meningkatkan pertumbuhan tanaman, hal ini berkaitan dengan pembelahan sel sel dan berpengaruh pada pertambahan diameter bonggol.

Pemberian kompos TKKS 112,5 g/polybag menunjukkan pertambahan diameter bonggol kelapa sawit tertinggi yaitu $2,25 \mathrm{~cm}$, sehingga menghasilkan diameter bonggol bibit di akhir penelitian sebesar 3,18 $\mathrm{cm}$ (sudah melebihi standar pertumbuhan). 
Pertambahan diameter bonggol pada dosis ini berbeda nyata dengan dosis $37,5 \mathrm{~g} /$ polybag dan 75 g/polybag. Hal ini dipengaruhi oleh ketersedian unsur hara makro yang cukup pada dosis $112,5 \mathrm{~g} /$ polybag, terutama unsur hara $P$ dan K. Suriatna (1988) menyatakan bahwa fosfor berfungsi untuk mempercepat perkembangan perakaran, berperan dalam proses respirasi, proses pembelahan sel dan metabolisme tanaman sehingga mendorong laju pertumbuhan tanaman diantaranya diameter bonggol.

Pertambahan diameter batang tertinggi di tunjukkan oleh dosis dolomit 27 g/polybag yaitu $2,18 \mathrm{~cm}$ dengan besar diameter bonggol diakhir penelitian sebesar $3,08 \mathrm{~cm}$ (sudah melebihi standar pertumbuhan). Hasil ini berbeda tidak nyata dengan besar diameter bonggol bibit pada dosis $18 \mathrm{~g} /$ polybag yaitu $3,06 \mathrm{~cm}$. Hal ini diduga disebabkan bahan makanan berupa hasil fotosintesis dan asimilat yang diperoleh oleh tanaman muda dimanfaatkan untuk pertumbuhan vegetatif yang meliputi perkembangan ujung akar dan ujung batang sedangkan untuk perkembangan diameter batang belum menunjukkan pertumbuhan yang optimal.

\section{Volume Akar, Rasio Tajuk Akar dan Berat Kering Bibit}

Tabel 3 menunjukkan bahwa kombinasi perlakuan kompos TKKS 112,5 g/polybag dan dolomit 27 g/polybag menunjukkan volume akar tertinggi, namun tidak berbeda nyata dengan kombinasi pemberian kompos TKKS 112,5 g/polybag dan dolomit pada dosis $9 \mathrm{~g} /$ polybag dan 18 g/polybag serta pada kombinasi kompos TKKS $75 \mathrm{~g} /$ polybag dan dolomit $18 \mathrm{~g} /$ polybag. Hal ini diduga karena pada kombinasi perlakuan dosis ini unsur hara tersedia bagi tanaman dan dapat diserap dengan baik oleh akar tanaman. Faktor kompos TKKS memberikan pengaruh yang berbeda nyata terhadap volume akar bibit kelapa sawit. Volume akar tertinggi ditunjukkan oleh pemberian kompos TKKS 112,5 g/polybag. Hal ini terjadi karena perubahan struktur tanah dengan aplikasi kompos TKKS akan mempengaruhi daya serap akar tanaman, semakin besar volume akar maka akan berpengaruh terhadap pertumbuhan dan produksi tanaman. Besarnya volume akar ini akan berpengaruh pada daya serap akar terhadap unsur P. Hartono (2007), menyatakan bahwa besarnya volume akar dipengaruhi oleh banyaknya serapan hara $P$ dalam tanah sehingga akan berdampak kepada hasil fotosintesis pada tanaman.

Tabel 3. Volume Akar, Rasio Tajuk Akar dan Berat Kering Bibit Pada Medium Sub Soil Inceptisol Setelah Pemberian Kompos TKKS dan Dolomit

\begin{tabular}{|c|c|c|c|c|}
\hline \multirow{2}{*}{$\begin{array}{c}\text { Kompos TKKS } \\
\text { (g/polybag) }\end{array}$} & \multicolumn{3}{|c|}{ Dolomit (g/polybag) } & \multirow{2}{*}{ Rata-rata } \\
\hline & 9 & 18 & 27 & \\
\hline \multicolumn{5}{|c|}{----- Volume akar (ml) ----- } \\
\hline 37,5 & $27,33 \mathrm{e}$ & $29,33 \mathrm{de}$ & $26,33 \mathrm{e}$ & $27,66 \mathrm{c}$ \\
\hline 75 & 35,66 cde & $39,73 \mathrm{abcd}$ & $38,83 \mathrm{bcd}$ & $38,07 \mathrm{~b}$ \\
\hline 112,5 & $42,33 \mathrm{abc}$ & $46,83 \mathrm{ab}$ & $50,13 \mathrm{a}$ & $46,43 \mathrm{a}$ \\
\hline Rata-rata & $35,11 \mathrm{a}$ & $38,63 \mathrm{a}$ & $38,63 \mathrm{a}$ & \\
\hline \multicolumn{5}{|c|}{----- Rasio tajuk akar ----- } \\
\hline 37,5 & $1,73 \mathrm{~b}$ & $2,20 a b$ & $2,00 \mathrm{ab}$ & $1,98 \mathrm{a}$ \\
\hline 75 & $2,10 a b$ & $1,85 \mathrm{ab}$ & $2,28 a b$ & $2,08 \mathrm{a}$ \\
\hline 112,5 & $1,90 \mathrm{ab}$ & $2,66 \mathrm{a}$ & $2,53 a b$ & $2,36 \mathrm{a}$ \\
\hline Rata-rata & $1,91 \mathrm{a}$ & $2,24 a$ & $2,27 a$ & \\
\hline \multicolumn{5}{|c|}{----- Berat kering bibit $(\mathrm{g})$----- } \\
\hline 37,5 & $14,91 \mathrm{c}$ & $15,01 \mathrm{c}$ & $15,56 \mathrm{c}$ & $15,16 \mathrm{c}$ \\
\hline 75 & $20,40 a b c$ & $19,43 \mathrm{bc}$ & $20,30 a b c$ & $20,04 b$ \\
\hline 112,5 & $22,67 a b$ & $27,02 \mathrm{a}$ & $26,88 \mathrm{a}$ & $25,02 \mathrm{a}$ \\
\hline
\end{tabular}

Keterangan: Angka yang diikuti oleh huruf kecil yang sama pada setiap perlakuan utama dan kombinasinya, tidak berbeda nyata menurut uji jarak berganda Duncan $5 \%$.

Harahap (2010), menyatakan bahwa pemberian kompos TKKS selain berpengaruh terhadap serapan $P$ yang merupakan unsur penting dalam pertumbuhan vegetatif, juga dapat mengubah struktur tanah Inceptisol dan meningkatkan $\mathrm{pH}$, sehingga akar lebih dapat berkembang dan lebih mudah menyerap unsur hara. Hal tersebut juga berhubungan dengan kandungan bahan organik. Menurut Hakim et al. (1986) semakin tinggi bahan organik maka akan semakin tinggi pula KTK. Tingginya bahan organik akan mengoptimalkan proses 
penyerapan unsur hara dan semakin banyak hasil fotosintat yang dihasilkan oleh tanaman.

Pemberian dolomit menunjukkan hasil yang berbeda tidak nyata terhadap volume akar bibit kelapa sawit. Volume akar tertinggi pada faktor ini ditunjukkan oleh dosis $18 \mathrm{~g} /$ polybag yaitu $38,63 \mathrm{ml}$. Hal ini dikarenakan pemberian dolomit secara tunggal belum mampu menyumbangkan unsur hara yang dapat mendukung perkembangan akar. Volume akar merupakan faktor penting dalam pertumbuhan tanaman yang mencerminkan kemampuan tanaman dalam penyerapan unsur hara serta metabolisme yang terjadi pada tanaman. Lakitan (1996) menyatakan sebagian besar unsur yang dibutuhkan tanaman diserap dari larutan tanah melalui akar, kecuali karbon dan oksigen yang diserap dari udara melalui daun.

Kombinasi kompos TKKS 112,5 g/polybag dan dolomit 18 g/polybag menunjukkan rasio tajuk akar tertinggi yaitu 2,66, namun berbeda tidak nyata terhadap semua kombinasi perlakuan kecuali pada kombinasi perlakuan kompos TKKS 37,5 $\mathrm{g} /$ polybag dan dolomit $9 \mathrm{~g} /$ polybag. Hasil rasio tajuk akar menunjukkan bagaimana penyerapan ditranslokasikan ke bagian-bagian tajuk tanaman. Gardner et al. (1991) menyatakan perbandingan tajuk dan akar mempunyai pengertian bahwa pertumbuhan suatu tanaman diikuti dengan pertumbuhan bagian lainnya dimana pertumbuhan tajuk akan meningkat apabila perkembangan akar juga meningkat.

Kombinasi pemberian kompos TKKS $112,5 \mathrm{~g} /$ polybag dan $18 \mathrm{~g} /$ polybag merupakan pertumbuhan tajuk dan akar terbaik, diduga dengan tingginya dosis pupuk organik yang diberikan berpengaruh baik terhadap sifat fisik, kimia dan biologi tanah sehingga mempengaruhi pertumbuhan bibit. Kombinasi kompos TKKS dan dolomit pada dosis ini berbanding lurus dengan pengamatan berat kering bibit, yang mana menunjukkan berat kering tertinggi yaitu $27,02 \mathrm{~g}$. Lingga dan Marsono (2006) menyatakan bahwa perkembangan akar sangat dipengaruhi oleh struktur tanah, air dan drainase di dalam tanah yang keadaannya sangat tergantung pada bahan organik tanah. Gardner et al. (1991) menyatakan jika unsur hara $N$ yang diperlukan tanaman telah mencukupi maka proses metabolisme tanaman meningkat salah satunya dalam proses fotosintesis, dengan demikian translokasi fotosintat ke akar juga akan besar sehingga sistem perakaran tanaman berkembang mengikuti pertumbuhan tajuk, sehingga akan terjadi keseimbangan pertumbuhan tajuk dan akar.

Kombinasi pemberian kompos TKKS

$112,5 \mathrm{~g} /$ polybag dan dolomit $18 \mathrm{~g} /$ polybag menunjukkan berat kering tertinggi, namun tidak berbeda nyata dengan kombinasi pemberian kompos TKKS $75 \mathrm{~g} /$ polybag dan $112,5 \mathrm{~g} /$ polybag dengan dolomit semua dosis kecuali $18 \mathrm{~g} /$ polybag. Hal ini diduga bahwa pemberian kompos TKKS 112,5 g/polybag dan dolomit 18 g/polybag telah mampu memperbaiki kondisi tanah, sehingga penyerapan unsur hara berjalan dengan baik dan meningkatkan unsur hara tanaman. Nyakpa et al. (1988), menyatakan bahwa pertumbuhan organ tanaman merupakan hasil pemanfaatan fotosintat dalam tanaman sehingga tanaman terus berkembang dan bertambah besar.

Data pada Tabel 3 menunjukkan bahwa pemberian kompos TKKS memberikan pengaruh yang berbeda nyata terhadap berat kering bibit kelapa sawit, dimana berat kering tertinggi ditunjukkan oleh pemberian kompos TKKS $112,5 \mathrm{~g} /$ polybag yaitu $25,02 \mathrm{~g}$. Hal ini dipengaruhi oleh unsur hara kalium yang dilepaskan dari dekomposisi kompos TKKS. Menurut Jumin (1992), bahwa unsur kalium berperan sebagai aktivator enzim dalam pembentukan karbohidrat yang berpengaruh terhadap berat kering tanaman, produksi berat kering tanaman merupakan proses penumpukan asimilat melalui proses fotosintesis. Hal ini didukung oleh Dwijosapoetro (1993) bahwa berat kering tanaman sangat dipengaruhi oleh optimalnya proses fotosintesis. Faktor dolomit memberikan pengaruh yang tidak berbeda nyata terhadap berat kering, namun cenderung meningkat jika dosisnya ditingkatkan dari 9 g/polybag hingga 27 g/polybag. Pemberian dolomit dapat meningkatkan aktifitas mikro organisme tanah, meningkatkan $\mathrm{pH}$, meningkatkan ketersediaan unsur hara sehingga sistem perakaran baik dan unsur hara yang diberikan dapat diserap. Selain itu pemberian dolomit juga menyediakan $\mathrm{Ca}$ dan $\mathrm{Mg}$ yang berperan dalam penyusun dinding sel, pembelahan sel dan pembentukan khlorofil sehingga menghasilkan fotosintat, sistem enzim dan pembentukan minyak, hal ini berpengaruh pada berat kering tanaman. Kuswandi (1993) menyatakan bahwa pemberian kapur dolomit akan memperbaiki sistem perakaran tanaman dan meningkatkan serapan hara, akibatnya akan meningkatkan proses fotosintesis tanaman dan akhirnya pertumbuhan tanaman semakin meningkat. 
Berat kering tanaman merupakan sumbangan dari tinggi tanaman, jumlah pelepah daun, panjang pelepah daun, dan diameter bonggol. Berat kering bibit juga berkaitan dengan jumlah pelepah daun, semakin meningkat jumlah pelepah daun, maka klorofil juga semakin meningkat sehingga jumlah fotosintat yang dihasilkan juga semakin banyak.

\section{KESIMPULAN}

Kombinasi pemberian kompos TKKS dengan dolomit berpengaruh nyata pada tinggi bibit, jumlah daun, volume akar, rasio tajuk akar dan berat kering. Perlakuan terbaik ditunjukkan oleh kombinasi kompos TKKS 112,5 g/polybag dengan dolomit 18 dan $27 \mathrm{~g} /$ polybag terhadap tinggi bibit, jumlah daun, diameter bonggol, volume akar, dan $\mathrm{pH}$ medium sub soil Inceptisol.

\section{DAFTAR PUSTAKA}

Badan Pusat Statistik Provinsi Riau. 2014. Riau dalam Angka 2013. BPS, Pekanbaru.

Darmosarkoro, W. Dan Winarna. 2001. Penggunaan TKS dan Kompos TKS Untuk Meningkatkan Pertumbuhan dan Produksi Tanaman. Pusat Penelitian Kelapa Sawit. Medan.

Dwijosapoetro, D. 1993. Dasar-Dasar Fisiologi Tanaman. Gramedium. Jakarta.

Fauzi, Y., Y.E. Widyastuti, I. Satyawibawa dan R. Hartono. 2002. Kelapa Sawit : Budidaya, Pemanfaatan hasil dan limbah. Penebar Swadaya. Jakarta.

Gardner, F.P.R.B Pear, dan F. L. Mitaheel. 1991. Fisiologi Tanaman Budidaya. Terjemahan Universitas Indonesia Press. Jakarta.

Hakim, N., Y. Nyakpa, A. Lubis, S. Nugroho, M. Saul, M.A. Diha, G.B. Hong dan H.H. Bailey. 1986. Dasar-dasar IImu Tanah. Universitas Lampung. Lampung.

Harahap, O. A. 2010. Pemanfaatan Kompos Tandan Kosong Kelapa Sawit dan Konsentrat Limbah Cair Pabrik Kelapa Sawit Untuk Memperbaiki Sifat Kimia Medium Tanam Sub Soil Ultisol Dan Pertumbuhan Bibit Kelapa Sawit (Elaeis guineensis Jacq.). Universitas Sumatera Utara. Medan.

Hardjowigeno, S. 2007. IImu Tanah. Akademika Presindo. Jakarta.
Hartono, J. 2007. Penelitian Umur Panen Optimal pada Tembakau Cerutu Besuki Tanam Awal. Jurnal Agri- tek Pertanian. Teknologi Pertanian Kehutanan. Vol. 14 (3) : $668-672$.

Ismanto. 1994. Pengaruh takaran dan penempatan kapur terhadap beberapa sifat kimia tanah typic dystropept terhadap pertumbuhan serta hasil jagung. Faperta Unand. Padang.

Jimianto dan Pongki. 2011. Pemberian kompos TKKS dengan aktivitor limbah cair PKS pada tanah ultisol dan responya terhadap pertumbuhan kelapa sawit di pembibitan utama. Fakultas Pertanian Universitas Riau. Pekanbaru.

Jumin, H,B. 1992. Ekologi Tanaman. Penerbit Rajawali. Jakarta.

Kuswandi. 1993. Pengapuran Tanah Pertanian. Kanisius. Yogyakarta.

Lalang Buana, Sunardi Adiputra, M. Thamrin Nst., dan Siti Habsyah. 2003. Abstrak Hasil Penelitian Pusat Penelitian Kelapa Sawit 1997-2000, Pusat Penelitian Kelapa Sawit (Marihat). Medan.

Lakitan, B. 1996. Fisiologi Pertumbuhan dan Perkembangan Tanaman. PT. Raja Grafindo Persada. Jakarta

Lakitan, B. 2010. Dasar-Dasar Fisiologi. Raja Grafindo Perkasa. Jakarta.

Lingga dan Marsono. 2006. Petunjuk Penggunaan Pupuk. Penebar Swadaya. Jakarta.

Notohadiprawiro, T., S. Soekodarmodjo dan E. Sukana. 2006. Pengelolaan Kesuburan Tanah dan Peningkatan Efisiensi Pemupukan. Repro Ilmu Tanah Universitas Gajah Mada.

Novizan. 2005. Petunjuk Pemupukan yang Efektif. Agromedium Pustaka. Jakarta.

Nyakpa, M. Y, A, M. Lubis. M, A. Pulung, Amrah, A. Munawar, G, B. Hong, N. Hakim. 1988. Kesuburan Tanah. Universitas Lampung Press.

Salisbury, F.B. dan C.W. Ross. 1995. Fisiologi Tumbuhan (Terjemahan D.R. Lukman dan Sumaryono). ITB. Bandung

Sarief, S. 1993. Kesuburan dan Pemupukan Tanah Pertanian. Pustaka Buana. Bandung.

Suriatna.1988. Pupuk dan Pemupukan. PT. Mediatama Sarana Perkasa. Jakarta

Sutejo. M.M dan AG. Kartasapoetra. 2002. Pupuk dan Cara Pemupukan. PT. Bina Angkasa. Jakarta. $177 \mathrm{hlm}$ Suriatna, S. 1988. Pupuk dan Cara Pemupukan. Melton Putra. Jakarta. 
Aplikasi Kompos Tandan Kosong Kelapa Sawit dan Dolomit pada Medium Sub Soil (Amri, $d k k$ )

Widiastuti dan T. Panji. 2007. Pemanfaatan tandan kosong kelapa sawit sisa jamur merang (Volvariella volvacea) TKSJ sebagai pupuk organik pada pembibitan kelapa sawit. Menara Perkebunan, 75 (2), 70-79. Balai Penelitian Bioteknologi Perkebunan Indonesia. Bogor. 